\title{
Optical Component Performance for the Ocean Radiometer for Carbon Assessment (ORCA).
}

\author{
Manuel A. Quijada, Mark Wilson, Eugene Waluschka, and Charles R. McClain \\ Goddard Space Flight Center, Greenbelt, MD 20771;
}

\begin{abstract}
The Occan Radiomctcr for Carbon Asscssment (ORCA) is a ncw design for the ncxt gencration remotc scnsing of ocean biology and biogeochemistry. ORCA is configured to meet all the measurement requirements of the Decadal Survcy Acrosol, Cloud, and Ecology (ACE), the Occan Ecosystcm (OES) radiometcr and the Prc-ACE climatc data continuity mission (PACE). Under the auspices of a 2007 grant from NASA Rescarch Opportunity in Space and Earth Scicnce (ROSES) and the Instrument Incubator Program (IIP), a tcam at the Goddard Space Flight Center (GSFC) has been working on a functional prototype with flightlike fore and aft optics and scan mechanisms. As part of the development efforts to bring ORCA closer to a flight configuration and in order to rcducc cost, wc have conducted component-lcvel optical testing using standard spcetrophometcrs and system-level characterizations using nonflight commercial off-the-shelf (COTS) focal plane array detectors. Although these arrays would not be able to handle flight data rates, they are adequate for optical alignment and performance testing. The purpose of this presentation is to describe the results of this testing performed at GSFC and the National Institutc of Standards and Tochnology (NIST) at the componcnt and systcm level. Specifically, we show results for ORCA's spectral calibration ranging from the near UV, visible, and near-infrared spcctral regions.
\end{abstract}

Keywords: ORCA, spcctral calibration, polarization, ACE, OES, $\mathrm{CO} 2$ rcmotc scnsor

\section{INTRODUCTION}

The Occan Radiometer for Carbon Asscssment (ORCA) is a ncw design concept for a next gencration occan color remotc scnsing satcllitc. A major goal for this is similar as in previous carth remotc scnsing mission such as the Earth Obscrving Systcm, including the Moderatc Resolution Imaging Spectroradiometcr ${ }^{1}$ (MODIS), and othcrs is to accuratcly mcasurc Top-of-Atmospherc (TOA) and surfacc-lcaving radiancc $L_{\omega}(\lambda)$. In occan-color rcmotc sensing, the sensor-mcasured radiance at the top of the occan atmosphere systcm, measurcd at wavelength $\lambda$, can bc writtcn as ${ }^{2}$

$$
L_{t}(\lambda)=L_{r}(\lambda)+L_{a}(\lambda)+L_{r a}(\lambda)+t(\lambda) L_{\omega c}+t(\lambda) L_{\omega},
$$

wherc $L_{r}(\lambda), L_{a}(\lambda)$, and $L_{r a}(\lambda)$ arc contributions, rcspectivcly, from the multiple scattcring of air moloculcs Raylcigh scattcring with no acrosols, acrosols no air molcculcs, and Raylcighacrosol intcractions. The $L_{\omega c}(\lambda)$ is the radiance at the sea surface that arises from sunlight and skylight reflecting from whitecaps on the surface, The $L_{\omega}(\lambda)$ is the watcr-lcaving radiance that is the desircd quantity in occan-color remotc scnsing to rclatc the occan ncar surfacc physical and bio-optical propertics and $t(\omega$ is the atmospheric diffuse transmittance that accounts for the effects of propagating $L_{\omega}$ and $L_{\omega c}$ from the sca surfacc to the TOA. In particular, this atmosphcric correction is the main challengc in converting measured TOA radiance $L_{r}$ to $L_{\omega}$.

Further author information: (Send correspondence to M.A.Q.)

M.A.Q.: E-mail: manuel.a.quijada@nasa.gov, Telephone: 13012863544 


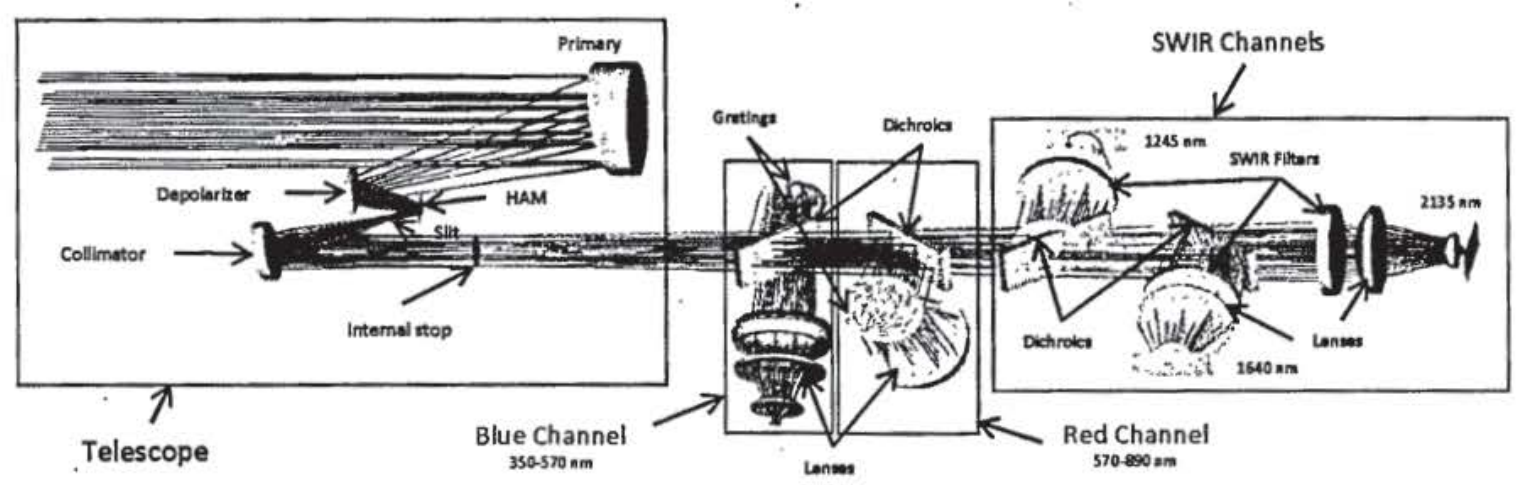

Figure 1. Diagram showing Collimator mirror and ORCA front-end optics.

\section{ORCA OPTICAL SYSTEM}

The devclopment of the design and testing of a ORCA prototype has becn under way at the Goddard Space Flight Center (GSFC) since 2007. This work has becn supported under the auspices of a NASA Rescarch of Opportunity in Spacc and Earth Scicnce (ROSES) and the Instrument Incubator Program (IIP). ORCA is cnvisioned as a possible successor to the ScaWif instrument. ${ }^{3}$ The instrument design reflects lessons learned from heritage sensors and is tailored to the new observational requircments recognized for advancing rescarch in occan biology and biogcochemistry. A sccond paper in thesc proccedings will present a more detailed optical design. ${ }^{4}$ The design requircments include a high spcctral rcsolution $(5 \mathrm{~nm})$ from UV through visiblc and shortwave infrarcd (SWIR) wavclengths $(350-2140 \mathrm{~nm})$. There will be a minimum of 26 aggregatc bands with a total signal-to-noisc (SNR) to cxcoed 1500 in most UV and visible aggregatc bands. There will be a 2-day global coverage at approx. $1.0 \mathrm{Km}$ resolution (noon/sun-synchronous orbit requircd). Other requirements arc:

- Minimal sun glint contamination (scnsor tilt requircd)

- Minimum polarization scnsitivity (polarization scrambler requircd)

- Minimum and well characterized out-of-band rcsponsc, clcctronic cross-talk, and stray light

- Minimal image striping

- No band saturation over bright targets

- Solar and lunar on-orbit calibration (spacccraft pitch mancuver or 90 tilt requircd)

- Complete sensor optical model and flight-like EDU

The observational requirements listed above reflect our new understanding of marine systems and their influence on occan optics. Thereforc, these requircments will not be met by any simple cxpansion of the ScaWiFS or MODIS designs. It is for this reason that thesc requircments have driven the optical design to include a grating spectrometer. Using diffractive gratings seems an obvious choice in order to simplify the optical design. However, this represents a challenge for a instrument with a polarization sensitivity requirement of less than $1 \%$, given that gratings themselves tend to producc a substantially polarizcd output beam (as a high as $40 \%$ ). The proposed solution has becn, like in ScaWifs, to incorporatc a depolarizer in order to producc a polarization insensitivc optical design. Another paper to be published in thesc procecdings will described in greater details the design and charactcrization of such depolarizcr. ${ }^{5}$

Figurc 1 has a layout of the ORCA optical systcm. The front-cnd part includcs a telcscope systcm with a primary mirror, depolarizcr, half-angle mirror (HAM) and slit. After the slit therc is a collimator mirror followed . by the spectrograph arca that is divided in threc main scetions: a bluc channel with spectral coverage from 350 




Figure 2. Typical Optical reflectance for ORCA pirmary, HAM, and collimator mirrors.

to $570 \mathrm{~nm}$, a red channcl that includes a wavclength range from 570 to $890 \mathrm{~nm}$, and a Short Wave Infrarcd (SWIR) channel with threc discrect bands at 1245, 1640, and $2135 \mathrm{~nm}$. Next sections will describe in morc details charactcrizations for the telcscopc optical clements as well as the optical componcnts that form part of ORCA threc main channcls.

\subsection{Telescope Optical Components}

The ORCA front-cnd optical systcm (a schcmatic of which is shown on the left side of Fig. 1) consists of a telescope with a primary mirror that collects collimated light from an object at infinity and images it onto a slit. But before the light reaches the slit, it is intercepted by a polarization scrambler with a reflective coating on the back side, and a double sided half-angle mirror (HAM), that folds the light on the slit as shown in Fig. 1. As mentioned carlicr, the purpose of this polarization scrambler is to reduce the polarization scnsitivity of the ORCA tclescopc. It is placed right after the primary mirror in order to prevent any polarization for the scenc under obscrvation to propagatc through the rest of the spcetrograph. The scanning mechanism is such that both primary mirror and HAM will rotatc in synchronization modc around samc axis with HAM rotating at half the specd as that of the primary.

\subsection{Primary Mirror}

The Primary Mirror (PM) of ORCA is a a off-axis ellipsoid (OAE) focusing mirror with a 90 mm clear aperture (100 mm physical diamctcr), whosc optical prescription is as follows. This mirror has vertcx radius of $600 \mathrm{~mm}$ with a focal length $(F 1)$ of $304 \mathrm{~mm}$ and off-axis focusing distance of $50 \mathrm{~mm}$. The surface figure error was specified to $\lambda / 20$ RMS. We performed micro roughness using a ADE Phase-Shift (MicroXAM model) surface profiler and wc found the RMS roughncss is $\sim 10 \AA$. We will discuss next the performance of the reflecting coating applied to the primary as well as the reflecting components such as the HAM, depolarizers and the collimator mirrors.

\subsection{UV-Enhanced Ag Coating}

Figurc 2 illustrate the performance of the coating uscd on the primary as wcll as the HAM mirrors. It is a proprietary version of UV-enhanced protected Ag coatings. The reflectance where measured using a Perking-Elmer 950 spectrophotometer fitted with a Universal Reflectance Accessory (URA) that provides absolute reflectance as function of wavclength $\left(200-3300 \mathrm{~nm}\right.$ ) and Anglc of Incidence (AOI) from $8^{\circ}$ to $68^{\circ}$. The reflectance data in Fig. 2, takcn at the nominal AOI of $15^{\circ}$, indicate this is a high-throughput coating with an average reflectance of $\sim 98 \%$ in the 350 to $2200 \mathrm{~nm}$ rangc. Thesc data also display interfercnce oscillations below $800 \mathrm{~nm}$ that arc most likcly caused by the diclcetric overcoats that most likcly arc uscd to protcet the Ag metal underncath and also to boost the reflectance around the natural roll-off of $\mathrm{Ag}$ that occurs below $400 \mathrm{~nm}$. The $4 \%$ reflectance cnhancement realized with this coating betwecn 350-400 nm (when comparcd to barc Ag) provided the deciding factor in choosing this coating for ORCA. This was requircd in order to mect the SNR requircment at the shortcst bluc-channcl band centercd at $350 \mathrm{~nm}$. We also investigatcd the polarization propertics for this coating 

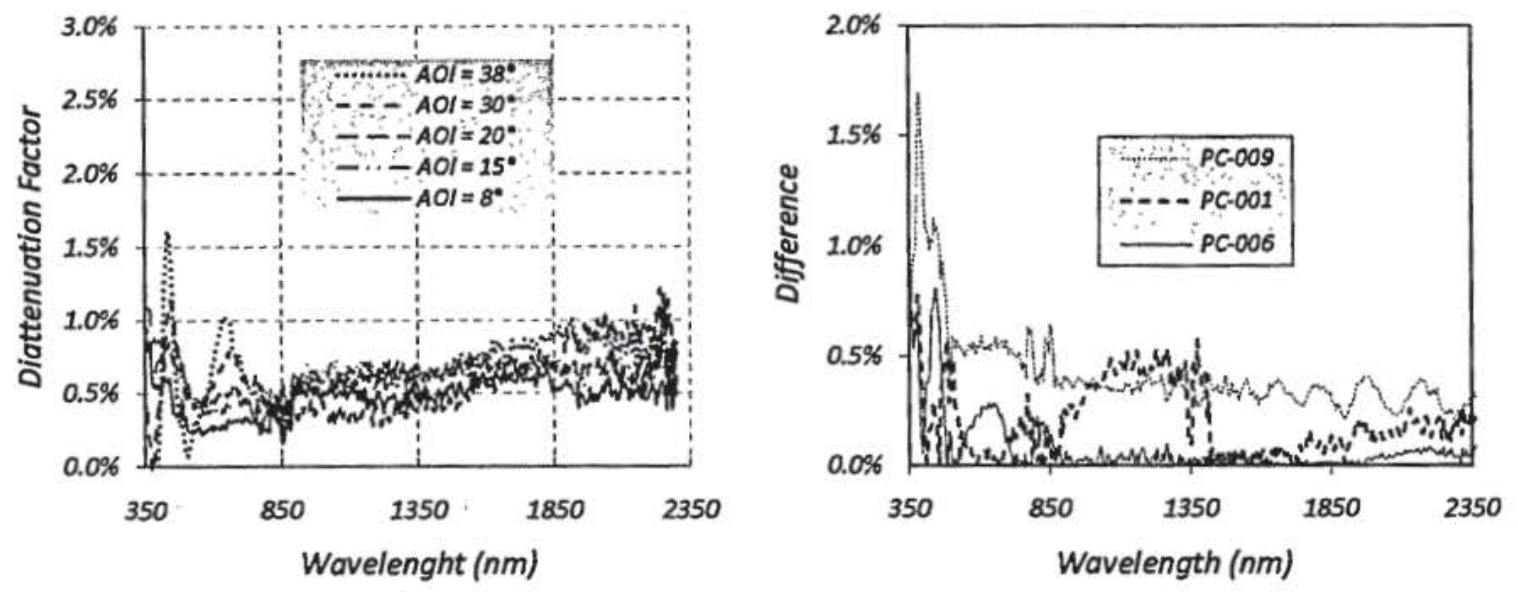

Figure 3. Polarization sensitivity data of UV-enhanced $\mathrm{Ag}$ coating obtianed from measured $R$, and $R_{p}$.

by measuring reflectance for $R_{w}$ and $R_{p}$ polarizcd light at various AOI from ncar-normal ( $8^{\circ}$ ) to about $38^{\circ}$. Wc then calculated a diattcnuation factor $(D F)$ that is defined by:

$$
D F=\frac{\left(R_{s}-R_{p}\right)}{R_{n}+R_{p}}
$$

The rcsults of these calculations arc shown on the left side of Fig. 3. These results suggest a UV-cnhanced Ag coating with a fairly low polarization sensitivity, with the avcrage $D F$ valuc below $1 \%$ for most of the rangc shown. Only for AOI cqual to or larger than $38^{\circ}$ we obscrve that $D F$ slightly cxcceds the $1 \%$ threshold specially at wavclengths shorter than $500 \mathrm{~nm}$.

Another consideration is how much variability there is in the coating process from onc run to the ncxt. This is very important given that the HAM optics will have both sides coated with the same reflecting coat. Hence in scanning modc, ORCA will be using onc side of the mirror half the timc, and the other side will be uscd the other half. The use given to this mirror impascs a very tight requircment from the instrument calibration point of view in that differences in reflectance from one side to the other would be kept to a minimum. The right panel in Fig. 3 shows the calculate reflectance difference from side 1 and side 2 of three HAM's that were coated. The results show a difference in response from either side that varies from sample to sample. The sample labeled "PC-006" offers the smallest $(\simeq 0.09 \%)$ average difference of the three, and for this reason this was HAM chosen to install on the instrument. Even though small differences could in principle be calibrated out, it is very reassuring how small the differences were (for mirror "PC-006" in particular) in the coating process used to produce this version of UV-cnhanced protected Ag.

\subsection{Depolarizer}

The depolarizer is a commercially available scrambler made by Karl Lambrecht. It is made using the principle of the Cornu depolarizer consisting of two matching wedged pieces of magnesium fluoride crystals that are glued together so that the optics axis of one is rotatcd $45^{\circ}$ with respect to the other picce. ${ }^{6}$ Any ray cntcring this optics effectively passes through these two wave plates. The thickness of these and therefore their retardance varies across the beam. For this reason, they are considered area depolarizer, since at different ray heights on the entrance face of the cube, different thicknesses of left-and-right-hand crystal are traversed resulting in an cxit polarization angle that is a function of ray hcight. Thus, the bcam will have its polarization statc mixcd over the beam facc. It is also worth mentioning that the phase shift, and hence polarization statc mixing arc also dependent on wavelength duc to dispersion in the glass. The manufacturer of this optic suggcsts using it in transmission mode where polarized light cnters on onc side and it cmerges unpolarized on the other. Howcver this is not the way in which it will be in the ORCA optical systcm. As the left pancl of Fig. 4 shows, we havc 



Figure 4. Left panel: Polarization scrambler used in reflectance mode made with two wedge pieces of magnesium fluoride. Right panel: Measured polarized reflectance on scrambler at a $\mathrm{AOI}=21^{\circ}$.
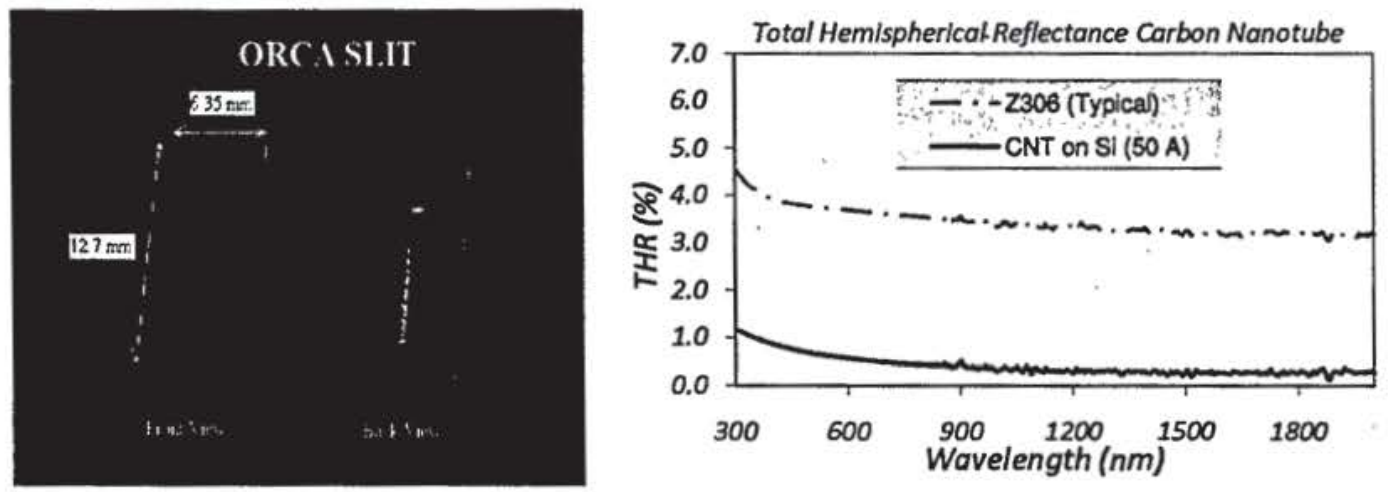

Figure 5. Left panel: Front and back slit image with external dimensions. Right panel: Spectral performance of Z306 and carbon nanotube black coatings on $\mathrm{Si}$ substrate.

coated one side of the optics with a reflective coating of protected internal Ag. Hence, the optics is used in a reflection mode (as shown on the left panel of Fig. 4), where the depolarizing effect occurs as the beam enters through the non-coated side, goes through the two segmented wedges, then it gets reflected on the coated back and cmerges on the same side with a $\mathrm{AOI} \simeq 21^{\circ}$. This is called a double-pass configuration and it is similar to what was donc in the ScaWiFS instrument. ${ }^{3}$

The right side of Fig. 4 display the measured reflectance of the scrambler coated on the back side with a proprietary internal Ag. The AOI was set in the same configuration as the optic will be used at the nominal valuc of $21^{\circ}$. The results in this figure show that the average reflectance is around $97 \%$. Although this value is lower than barc $\mathrm{Ag}$ over the same wavelength range, it is consistent with the expected losses as light travels through the $\mathrm{MgF} 2$ glass.

\subsection{Slit}

The right side of Fig. 5 shows an image the slit used in ORCA. The front and rear surfaces are flat, while the opening in the rear side is beveled at $45^{\circ}$ on cach side to remove the possibility of vignetting as the light gocs through it. It is made out of silicon substrate and its main function is to define the instrument field of view (IFOV) at the detector focal planc location. The dimensions of the clear opening are detcrmincd through a ray-tracing optical model to cnsurc that ORCA mcets is statcd optical performance requircments. For instance the long dimension $(\sim 8.0 \mathrm{~mm})$ is in the along-scan (or spatial) dircetion and it is rclated to the instrument 




Figure 6. Average reflectance and transmittance curves for the blue-channel dichroics. The dashed line represents the specification given to the vendor prior to fabrication.

requircment of being able to resolve $1.0 \mathrm{Km}$ targets on the ground. Similarly, the narrow $(\sim 0.65 \mathrm{~mm})$ is along the across-scan (or spectral) dircetion and it sets the maximum spcctral resolution.

Given the fact that the slit is located at the telescope best focus, it is required that light that bounces off docs not become a source of scattcred light that may contaminate the signal that gocs through. The solution is to have an absorbing coating on the slit to reducc this possible source of stray light. To this cnd, we considered two alternatives: one was a conventional Z306 black pain that has a long heritage in spaceflight application. The sccond onc was a Multi Walled Carbon Nanotube (MWCNT) coating that have bocn shown to represent the blackest matcrials known in naturc. ${ }^{7}$ To further cvaluate the suitability of cither of the two, the right pancl of Fig. 5 shows total hemispherical reflectance (THR) measured on representative coatings for each of the two. These results show that indecd, the MWCNT coating has an almost factor of 10 bcttcr performance in terms of its ability to absorb light over the wavelength range shown in the figure. These results were a deciding factor in choosing the MWCNT on the ORCA slit that was cventually installod in the instrument. Another deciding factor was the fact that silicon is the idcal substratc on which to grow the MWCNT.

\section{SPECTRAL RESPONSE}

We now turn our attention at spcetral charactcrization of the optical components in ORCA throc main channcls. The diagram in Fig. 1 show the arrangement of these with the blue channel being the first after the collimating mirror. The bluc spectrograph is followed by the red channcl and the threc Short Wave Infrarcd single channcls at the back cnd of the instrument. The following sections arc organizcd according to the sequence in which these optical components appear in the instrument's optical train. Hence, we will discuss first the optical response of the dichroic bcamsplittcrs.

\subsection{Dichroics}

The current design of the ORCA radiometer uses four dichroics. In the ORCA application, these dichroics transmits light for wavelengths above a reference wavelength in the dichroics design and reflect light below the reference wavelength. These dichroics perform a pre-filtering of the radiance from the earth, limiting the range of wavelengths that reach the next optics in each of the five focal planes.

The dichroics and focal planc asscmblics in ORCA arc shown in schematic form in Fig. 1. In the schematic, the first or blue-channel dichroic, which is set at AOI of $45^{\circ}$, reflects light in the $350-570 \mathrm{~nm}$ range onto the next optics in this channcl. This dichoric is designed to transmit light in the $570-2200 \mathrm{~nm}$. This light bundle is next intercepted by a sccond red-channcl dichroic. This sccond dichroic sct at a AOI of $45^{\circ}$, performs a sccond splitting of the light, reflecting wavelengths in the $580-890 \mathrm{~nm}$ range and transmitting radiance in the 900-2200 


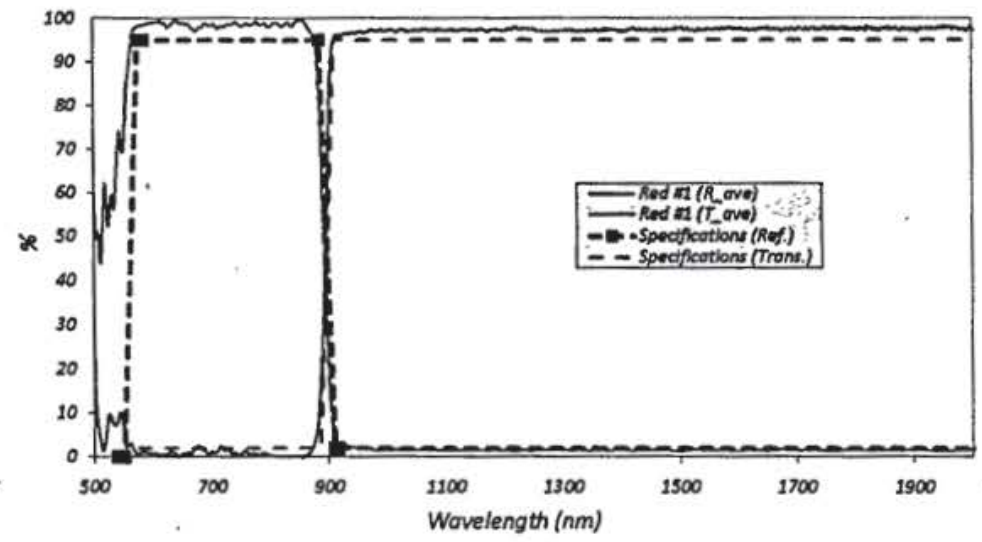

Figure 7. Average reflectance and transmittance curves for the red-channel dichroics. The dashed line represents the specification given to the vendor prior to fabrication.

nm range. Two more dichroics in the SWIR channel perform more pre-filtering for the three remaining bands in this channel. The SWIR dichroic 1 reflects energy in the 1230 to $1255 \mathrm{~nm}$ range. The transmitted light bundle is next splitted by a second SWIR dichroic 2 by reflecting radiance in $1600-1650 \mathrm{~nm}$ and transmitting light above $1700 \mathrm{~nm}$ on to the last SWIR band centcred at $2135 \mathrm{~nm}$.

Figure 6 gives the spectral response in the form of the average reflectance and transmittance for the ORCA blue-channel dichroic as a function wavelength. This figure show the in-band average reflectance and transmittancc arc $>97 \%$ both cases indicating an excellent performance in this regard, when compared to specifications. However, the cut-off for the last $90 \%$ reflection point for this dichroic falls at $554.9 \mathrm{~nm}$. This should be compared with the specification that the $90 \%$ wavelength be at $568 \mathrm{~nm}$. It is evident that the vendor, missed the specified cut-off by about $13 \mathrm{~nm}$. This is significant since the last band in the blue channel is centered at $555 \mathrm{~nm}$ (with a bandwidth of $15 \mathrm{~nm}$ ). This caused the instrument to miss the $1 \%$ polarization requircment for this band only, given that it falls in the dichroic transition region (550 to $570 \mathrm{~nm}$, where this optic produccs a strongly polarized (sim100\$) output. We should point out that moving the design cut-off upward by at least $15 \mathrm{~nm}$ will resolve this non-compliance polarization issuc for this particular band. Howcver, this may also require a tightening of the transition width range to minimizc any loss in throughput from the adjacent red-channcl band.

Figure 7 gives the average reflectance and transmittance for the ORCA red-channel dichroic as a function wavelength. We find that the in-band average reflectance and transmittance are $98 \%$ in both cases indicating an excellent performance in this regard. Also, the cut-off for the last $90 \%$ reflection point for this dichroic falls at $883.5 \mathrm{~nm}$. This is in cxcellent agrecment with the requircment of $885.0 \mathrm{~nm}$.

Table 1. List of dichroics along with their corresponding center wavelengths and bandwidth parameters.

\begin{tabular}{|c|c|c|c|c|c|c|c|}
\hline Dichroic Namc & $\begin{array}{c}\lambda_{0} \\
(\mathrm{~nm})\end{array}$ & $\begin{array}{c}\mathrm{R}_{\text {ave }} \\
(\%)\end{array}$ & $\begin{array}{c}\text { FWHM } \\
(\mathrm{nm})\end{array}$ & $\begin{array}{c}\lambda_{\text {cut-on }}(50 \%) \\
(\mathrm{nm})\end{array}$ & $\begin{array}{c}\lambda_{\text {cut-off }}(50 \%) \\
(\mathrm{nm})\end{array}$ & $\begin{array}{c}\lambda_{\text {cut on }}(1 \%) \\
(\mathrm{nm})\end{array}$ & $\begin{array}{c}\lambda_{\text {cut-off }}(1 \%) \\
(\mathrm{nm})\end{array}$ \\
\hline Bluc & 437.7 & 96.8 & 234.2 & $<300$ & 568.4 & N/A & 577.1 \\
\hline Rcd & 721.8 & 98.3 & 323.3 & $<536$ & 892.7 & N/A & 904.7 \\
\hline SWIR \#1 & 1200.5 & 98.0 & 140.8 & $<1101$ & 1307.4 & N/A & 1332.9 \\
\hline SWIR \#2 & 1632.0 & 94.9 & 165.9 & $<1555$ & 1721.1 & 1564.4 & 1749.8 \\
\hline
\end{tabular}



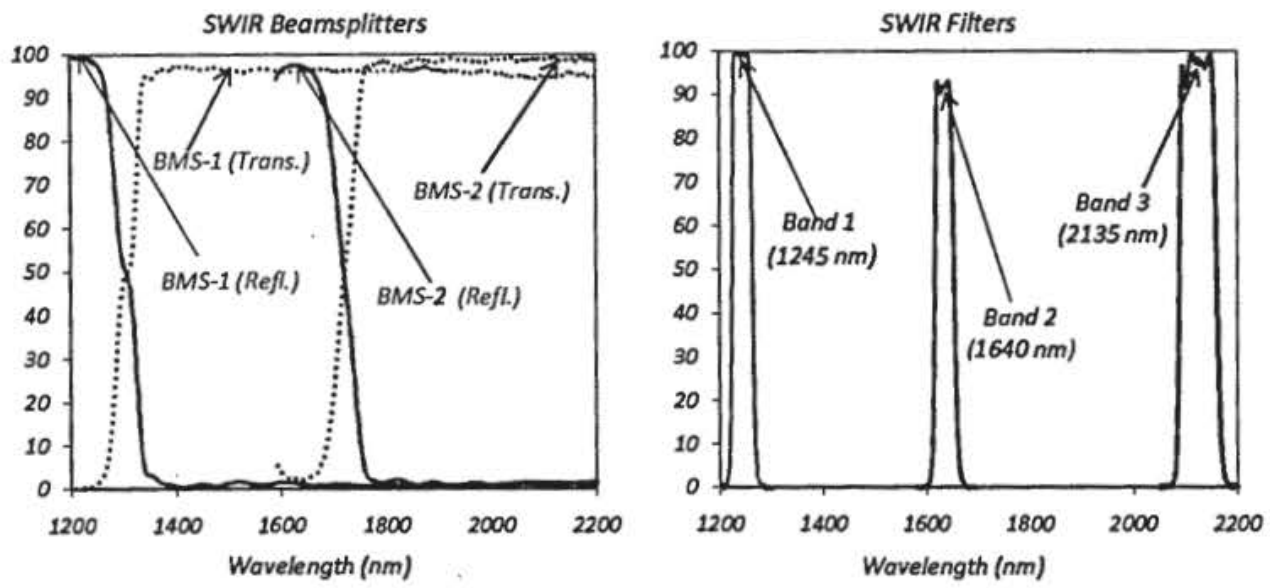

Figure 8. Left panel: Reflectance and transmittance for SWIR beamsplitters 1 and 2. Right panel: Transmittance for the band-pass filters for the three SWIR bands.

\subsection{SWIR Optics}

The left panel of Fig. 8 gives the average reflectance and transmittance for the two dichroics beamsplitters in SWIR channcls. These spcctra wcrc collccted at the opcrating anglc of incidcnce of $45^{\circ}$. The first one labeled "BMS-1" splits the beam of light into a reflected component (1130-1270 nm) and a transmitted one (1270-2200 $\mathrm{nm}$ ). The sccond dichroic (BMS-2) intcrecpts the transmittcd component from BMS-1 and performs a sccond split into a reflected $(1575-1690 \mathrm{~nm})$ component and a transmitted one (1690-2200). The right side of Fig. 8 displays the transmission shape for each of the three SWIR dichroic filters. These are the optics that define the actual bandpass for cach of the thrce SWIR bands at 1245, 1640, and $2135 \mathrm{~nm}$. They arc placed in front of the respective lenses that re-image the collimated beam on the back on the corresponding focal plane detcctors. The filter responses give the principal definition of the SWIR bands in terms of: throughput from the average transmission, the centcr wavelength; the band cdges from the full-width-half-maximum, and the extended band edges from the $1 \%$ points. Tables 1 and 2 give a summary for all the dichroic and filter parameters derived from

Table 2. List of narrow band-pass filters, along with their corresponding center wavelengths and bandwidth parameters.

\begin{tabular}{|l|c|c|c|c|c|c|c|}
\hline Filtcr \# & $\begin{array}{c}\lambda_{0} \\
(\mathrm{~nm})\end{array}$ & $\begin{array}{c}\mathrm{T}_{\text {ave }} \\
(\%)\end{array}$ & $\begin{array}{c}\text { FWHM } \\
(\mathrm{nm})\end{array}$ & $\begin{array}{c}\lambda_{\text {cut-on }}(50 \%) \\
(\mathrm{nm})\end{array}$ & $\begin{array}{c}\lambda_{\text {cut-off }}(50 \%) \\
(\mathrm{nm})\end{array}$ & $\begin{array}{c}\lambda_{\text {cut-on }}(1 \%) \\
(\mathrm{nm})\end{array}$ & $\begin{array}{c}\lambda_{\text {cut-off }}(1 \%) \\
(\mathrm{nm})\end{array}$ \\
\hline Filtcr 1 & 1242.2 & 98.7 & 39.9 & 1222.5 & 1262.4 & 1218.0 & 1267.4 \\
\hline Filtcr 2 & 1634.0 & 91.1 & 38.0 & 1616.4 & 1654.4 & 1611.7 & 1661.3 \\
\hline Filtcr 3 & 2134.0 & 96.6 & 72.0 & 2089.3 & 2161.2 & 2084.0 & 2169.0 \\
\hline
\end{tabular}

data shown in Figurcs 6,7 and 8. Ovcrall we obscrve these optics show good to cxcellent performance that will cnablc ORCA to mects its stated optical performance requircments.

\subsection{Gratings}

As discussed previously in Scc. 2, the hypcrspectral nature of ORCA along with its high spectral resolution requircments have driven the design to include gratings to provide proper dispersion of the light. This scems an obvious choice given that diffraction gratings are optical components used to spatially separate polychromatic light (whitc light) into its constitucnt optical wavclengths. The simple grating consists of glass substratc with a series of parallel, equally spaced lines on the front surface of the glass. Diffraction gratings are used in such diverse fields as spectroscopy, colorimetry, metrology and laser optics. The next question is to determine the grating parameters, from an optical design model perspective, in order to meet the specifics application needs. 

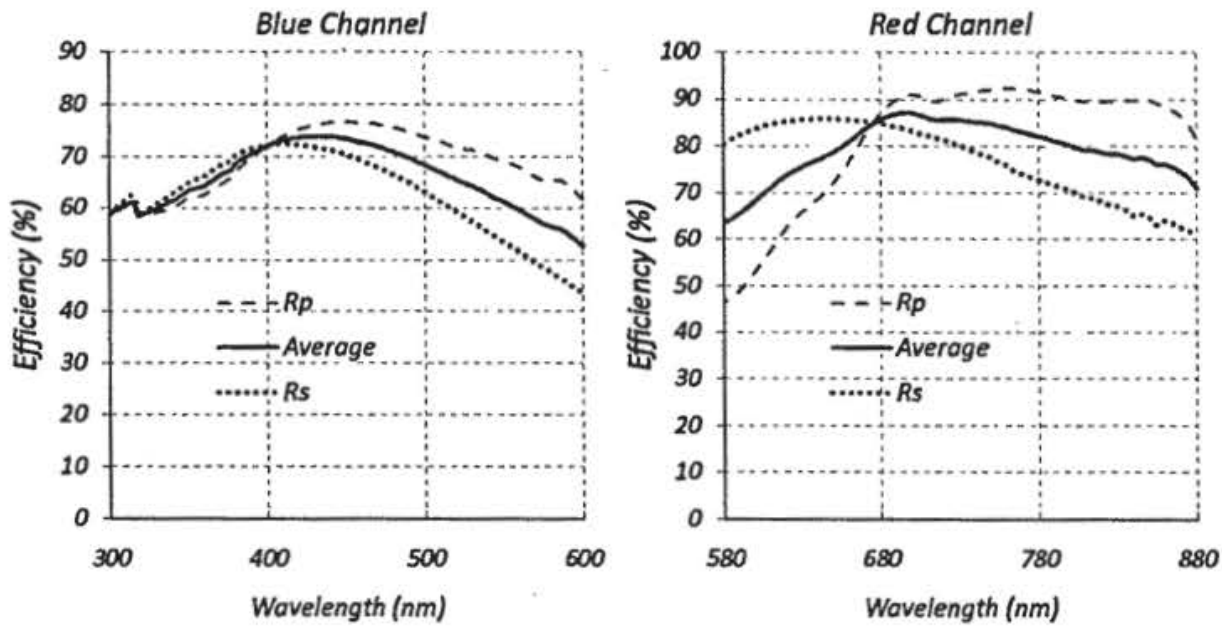

Figure 9. Left panel: Reflectance and transmittance for SWIR beamsplitters 1 and 2. Right panel: Transmittance for the band-pass filters for the three SWIR bands.

In the casc of ORCA, its spectral resolution requircment is such that it will requirc projection of a monochromatic beam of light to cover an arca on the focal planc of roughly $5 \mathrm{~nm} /$ supcrpixcl, wherc onc supcrpixcl is cqual to 8 physical pixcls with dimensions of $26 \times 26 \mu \mathrm{m}$. ${ }^{4} \mathrm{Hcncc}$, it follows that the grating parametcrs can bc detcrmincd from the grating cquation:

$$
d(\sin \alpha \pm \sin \beta)=\mathrm{m} \lambda,
$$

wherc, $\alpha$ is angle of incidence, $\beta$ is the angle of diffraction, $d$ is the distance betwecn adjacent grooves, $\mathrm{m}$ is the order (integer number) and $\lambda$ is the wavclength of the incident bcam. It is clear from Eq. 3 that the condition for the formation of a diffracted order depends on the wavelength, $\lambda$, of the incident light. Hencc, to consider the formation of a spectrum we need to know how the angle of diffraction varies with the incident wavelength. This is found by differentiating Eq. 3 with respect to $\beta$, assuming the anglc of incidence is constant:

$$
\frac{\mathrm{d} \beta}{\mathrm{d} \lambda}=\frac{\mathrm{m}}{d \cos \beta} .
$$

The quantity $d \beta / d \lambda$, also known as the angular dispersion, is the change of diffraction angle corresponding to a small change of wavelcngth. Finally, the lincar dispersion of a grating is the product of this term and the effective focal length of the optical system.

Another consideration to takc into account in the casc of ORCA is the physical size of the slit along the spectral direction (the narrow dimension of the slit image shown in Fig. 2.5). The specifics of how the equations abovc werc used to detcrmine the grating parameters for the ORCA instrument arc discussed clscwherc. ${ }^{4}$

In addition to the dispersion requirements given above, the gratings were required to be flat and that conventionally ruled gratings will provide the minimum required average efficiencies across each of the ORCA blue and red channels. Finally, the gratings were used in such a way that there was not much difference between angle of incidence and the angle of the proper diffracted order $(\alpha \sim \beta)$. This is was donc to avoid anamorphic magnification of the slit image at the instrument focal plane. Figure 9 has the measured efficiencies for the two gratings used on the ORCA instrument. The left panel of this figure gives the data for the blue channel in the 300-600 nm rangc, whercas the right pancl shows results for the red grating over the 580-880 nm rangc. Polarized and average efficiencies are plotted as a function of wavelength and these were measured at the appropriate AOI for cither grating $\left(28^{\circ}\right.$ for the bluc and $35^{\circ}$ for the red channels). We notice the measured efficiencies are at $60 \%$ or higher for both gratings. The polarization scnsitivitics arc $<10 \%$ for the bluc grating, whilc it is $<30 \%$ for the red onc. A summary of these results arc in shown in Table 3 where we also show the groove density for thesc gratings as wcll. 
Table 3. Grating parameters for ORCA blue and red channels.

\begin{tabular}{|c|c|c|c|c|c|}
\hline Channcl & Groove Dcns. & Ordcr & AOI & Efficiency & Pol. Scn. \\
\hline Bluc & 818 lincs $/ \mathrm{mm}$ & 1 st & $28^{\circ}$ & $>60 \%$ & $<18 \%$ \\
\hline Rod & 703 lincs $/ \mathrm{mm}$ & 1 st & $35^{\circ}$ & $>60 \%$ & $<30 \%$ \\
\hline
\end{tabular}

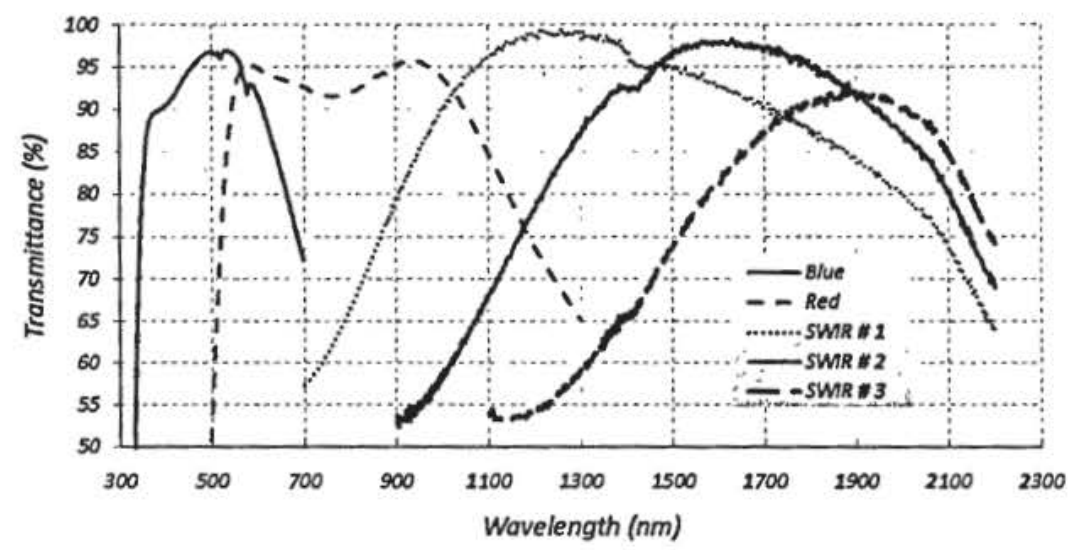

Figure 10. Total throughput for each lens assembly in ORCA five channels.

\subsection{Lenses}

The last optical element before the detector at each of ORCA five channels is a lens assembly. Each of the lenses picks up the collimated (and dispersed output of the gratings in the bluc and red channcls) and form an image of the light going through the slit on the back of the asscmbly at bcst focus where the CCD detcetors will be located. The imaging performance requircments are such that these lenses would correct for known abcrrations of ORCA (OAE) primary, while producing focuscd spots at the cdges of the slit image (both spcetral and spatial) of 1 physical pixcl diameter, with a minimum of slit curvaturc. The bluc-channel lcns clements wcre constructcd out of I-line glass matcrials, whercas standard Schott glass was the matcrial of choicc for the red-channcl lens clcments. The design requircments for both of those two lenscs were fully met with all sphcrical surfaccs. The elements in all three SWIR channels were made out of LAK9G15 glass. The throughput in each of the five lenses was maximized by the application of anti-reflection (A/R) coatings to reduce reflection losses. Those A/R coatings wcre tunc to match the respcctive band-pass for cach of the channcls. Figurc 10 display the throughput performance in each of the five lenses from measured transmittance as function of wavelength over the full ORCA bandpass rangc. These results show the $A / R$ coating application was succossful in maximizing the transmission in each of channel in-band spectral range. We find that for the blue band, the average in-band transmission is $\sim 93.5 \%$. Likcwisc, the red-channcl transmission is $\sim 93.1 \%$. Finally, the corrcsponding transmission valucs for the SWIR arc $98.9 \%, 97.7 \%$, and $81.2 \%$ for channcls 1 through 3 respectivcly.

\section{SYSTEM-LEVEL PERFORMANCE}

We arc now in a position to calculatc the total systcm-level throughput from the picco-part data we have shown in previous scetions. Thesc results will be of great importance when cvaluating ORCA radiometric calibration and performance, as these results will form the basis to conclude whether ORCA will mcet its stated radiomctric science goals.

\subsection{Throughput}

The left panel of Fig. 11 illustrates the total efficiency response form the blue and red channels of ORCA. These curves arc derived by multiplying through the avcrage spectral rcsponsc of cach of the components in the ORCA optical train, including the grating efficiencies. An analysis of these results when compared to typical 

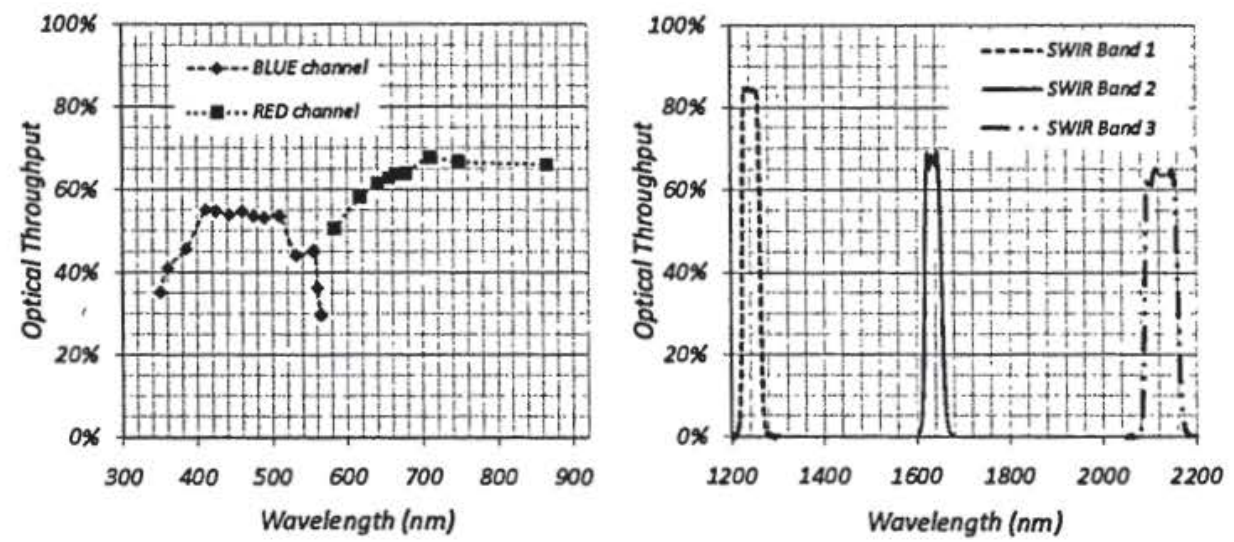

Figure 11. Total throughput for ORCA radiometer calculated from piece-part component data for blue and red channels (left) and three SWIR bands (right).

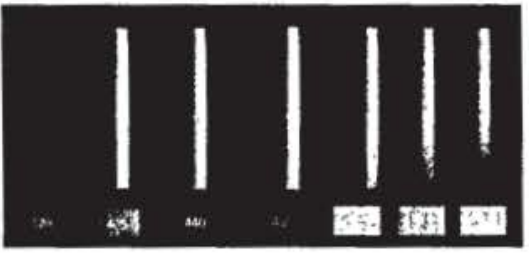

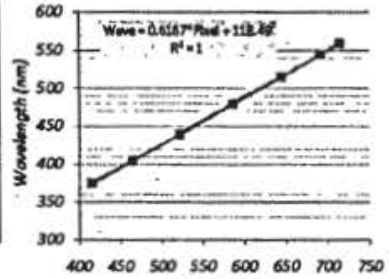

Plowilocotion
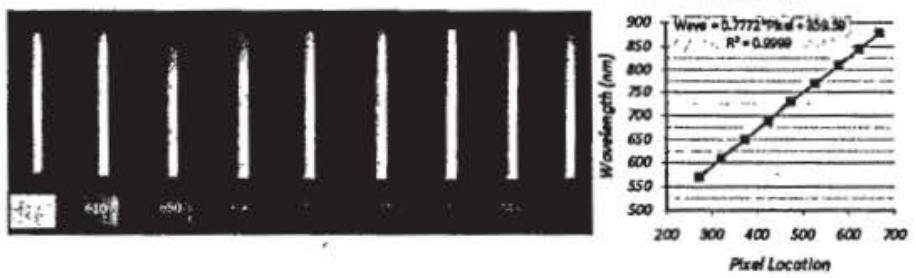

Figure 12. Left panel: Collection of slit images at variuos laser wavelengths for ORCA blue (top) and red (bottom) channels. Right panel: Linear plot of wavelength vs pixel location fro the corresponding images on the left.

surfacc-leaving radiance indicatc that ORCA will mect or cxccod the radiometric performance of cither MODIS or ScaWif. Thesc calculations show that ORCA should have not problem in mecting its sensitivity requircment goals in order to deliver occan-color data product over the 20 aggregated bands in the 350-885 nm wavelength range. The overcall efficiency is decidedly lower in the blue channel, when compared to the red-channel results. Howcver, we should point out that measuring surfacc-leaving radiance in the red-channel spectral range will be more challenging given that signals there arc much weaker. Hence, the higher sensitivity from these picco-part data would compensate for these weaker signals in the red band. The right pancl Fig. 11 shows similar calculations done for the threc bands in the SWIR channel. We should notice that these curves provide information about the total throughput ns wcll as the spectral bandwidth for cach of thosc bands. This is on account that narrow-band filters are used to define the transmission band-pass in each of the three SWIR channels. We will discuss next dispcrsion information about the bluc and channcls.

\subsection{Dispersion}

As mentioned previously, the ORCA optical design incorporates gratings in the bluc and red channcls to provide the proper wavclength sorting. Bccause of how gratings arc implemented in this design, it is not possible to get the 
overall systcm dispersion charactcristics by just looking at the grating dispersion propertics alonc. The approach we followed was to perform system-level characterization using non-flight commercial off-the-shelf (COTS) focal planc array detcctors. The format for thesc arrays is $256 \times 1032$ with individual pixcl sizc of $26 \times 26 \mu \mathrm{m}$. They arc placed at best focus behind the respective bluc and red-channcl lens asscmblics. Although thcse arrays are oversized and they would not be able to handle flight data rates, they are adequate for optical alignment and performance testing. The testing configuration consisted of placing ORCA in front of an integrating sphere that was couplcd to a tunable laser that allowed the instrument to be illuminatcd with monochromatic light of known wavelength. The sphere had an apcrture larger than that of ORCA in order to have the slit uniformly illuminated. A scrics of images were recorded at varying lascr wavelengths. Performing these tcsts required relocating the instrument to onc of the radiometric laboratorics at the National Institutc of Standards and Tochnology (NIST).

The left pancls of Figure 12 show results of a scrics of images taken at various laser wavclengths in the corresponding spectral range for the blue (top) and red (bottom) channels of ORCA. These figures show projections of the slit images on the CCD arrays of cither channcl. The horizontal dimension corresponds to the spectral dircetion, whereas the vertical dircetion is the spatial dircetion. The cxtend and scparations of the slit images provide information about the instrument dispersion propertics. For instance, the full-width-half-maximum along the spectral dircetion for the slit images shown in Fig. 12 arc $\sim 6$ and $\sim 7$ pixcls for the bluc and red channcls respectivcly. The cxtend along the vertical (spatial) dircetion is roughly 135 pixcls. Detcrmination of the centroid for each of these to find their location on the CCD arrays and plotting these pixel locations vs thcir corrcsponding wavelengths allowed us to estimate the overall instrument dispersion and wavelength calibration performance. The right pancls of Fig. 12 show the results of thcsc analysis. In the casc of the bluc channcl, the slope yiclds a value of $0.62 \mathrm{~nm} / \mathrm{pixcl}$ whilc this number is $0.78 \mathrm{~nm} / \mathrm{pixcl}$ for the red band. Given that a superpixel in ORCA consists of 8 physical pixels, we find the overall dispersion is roughly $4.96 \mathrm{~nm} / \mathrm{superpixel}$ for the bluc and $6.2 \mathrm{~nm} / \mathrm{supcrpixcl}$ for the red channcl. A comparison of these numbers with predictions from the optical design modcls suggest that these numbers are right on target for bluc channel, whilc only slightly highcr for the red-channcl dispersion requircment.

\section{CONCLUSIONS}

In conclusion, the results obtaincd from component-level optical testing have validatcd the robustncss of the optical systcm design for ORCA. All the optical components used in the ORCA prototype have becn made using existing technology and their excellent performance have brought ORCA closer to a flight configuration. The predicted optical throughput from picce-part data, the systcm-lcvel dispcrsion mcasurcment and polarization scnsitivity results have shown ORCA is in a position to mect or cxcoed the radiometric requircments of the Docadal Survcy Acrosol, Cloud, and Ecology (ACE), the Occan Ecosystcm (OES) radiomctcr and the Prc-ACE climatc data continuity mission (PACE).

\section{ACKNOWLEDGMENTS}

We would like to acknowledgc Stcve Brown, Ping-Shinc Shaw, and Kcith Lykke (National Institutc of Standards, Gaithcrsburg, MD) for thcir invaluable assistance during ORCA optical testing activitics at NIST. Wc would like to acknowledgc Alan Holmes (SBIG, Inc., Santa Barbara, CA) for his insight in the radiometric calibration tochniques uscd on ScaWif and their application to ORCA. Finally, we would also like to thank Tim Madison from the Optics Branch (NASA-GSFC, Grecnbelt, MD) for his help during the intcgration and alignment phase of the ORCA prototypc.

\section{REFERENCES}

1. Gcrhard Mcister, Ewa J. Kwiatkowska, Bryan A. Franz, Fredcrick S. Patt, G. C. Fcldman and C. R. McClain, "Modcratc-rcsolution imaging spectroradiometcr occan color polarization corrcction," Applied Optics 44, pp. 5524-5535, 2005.

2. R. B. Menghua Wang, Bryan A. Franz and C. McClain, "Effects of spectral bandpass on seawifs-retrieved ncar-surfacc optical propertics of the occan," Applicd Optics 40, pp. 343-347, 2001. 
3. Charles R. McClain, Genc C. Feldman, Stanford B. Hooker, "An overvicw of the ScaWIFS project andstratcgics for producing a climatc rescarch quality global occan bio-optical time serics," Deep-Sea Res. II 51, pp. 5-42, 2004.

4. Mark E. Wilson, Charles McClain, Bryan Monosmith, Manucl Quijada, Eugcnc Waluschka, Patrick L. Thompsona, Stcven Brown, "Optical design of the occan radiometcr for carbon assessment," in Earth Observing Systems XVI, Proc. SPIE 8153, 2011.

5. Eugenc Waluschka, Mark Wilson, Manucl Quijada, Brcndan McAndrcw, Lcibo Ding, "Orca depolarizcr," in Polarization Science and Remote Sensing V, Proc. SPIE 8160, 2011.

6. Edward Collcct, Field Guide to Polarization, SPIE Ficld Guide vol. FG05, SPIE Prcss, Bcllingham, Washington, 2005.

7. John G. Hagopian, Stcphanic A. Getty, Manucl Quijada, Junc Tveckrcm, Ron Shiri, Patrick Roman, James Butler, Georgi Georgiev, Jeff Livas, Cleophus Hunt, Alejandro Maldonado, "Multiwalled carbon nanotubes for stray light suppression in space flight instruments," Proc. SPIE 7761, p. 77610F, 2010. 